\title{
La fotografía documental y la utopía
}

\author{
Beatriz Guerrero González-Valerio | beguergo@ceu.es \\ CEU Universidad San Pablo
}

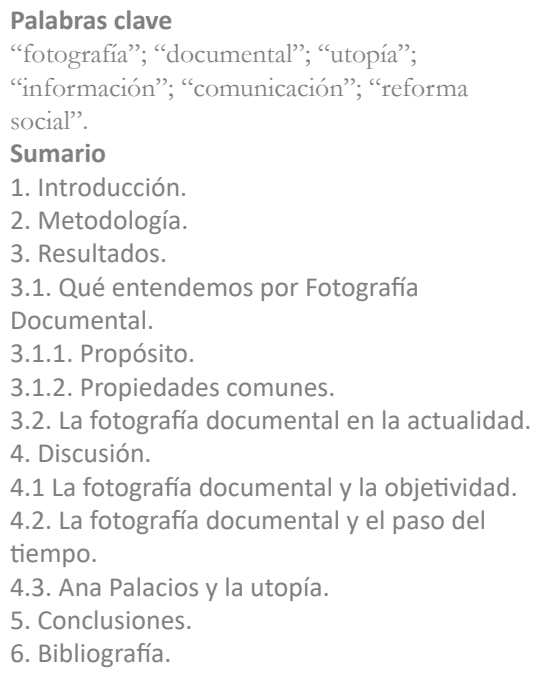

\section{Resumen}

La fotografía documental se distingue porque hace uso de la cámara como instrumento que le permite dar a conocer una determinada situación. Por tanto, no solo hay un compromiso con la realidad, sino que se confía en la capacidad de convicción de la imagen fotográfica. Esta intención documental en la fotografía no se manifestará hasta los inicios del siglo XX. Su nacimiento tiene lugar en Estados Unidos, de la mano de Jacob Riis y de Lewis Hine, ambos realizan fotografías de temática social abogando porque se enmendasen ciertas injusticias. En los inicios del siglo XXI podemos constatar que las imágenes documentales siguen existiendo y funcionando. Dos serán las cuestiones que trataremos de esclarecer a lo largo del presente artículo, en primer

lugar, qué se entiende por fotografía documental, qué características debe tener una imagen para ser considerada documental y, en segundo lugar, constatar si la fotografía documental actual sigue interesada en reformar, si sigue buscando persuadir a sus coetáneos de la necesidad de enderezar el mundo. Para dar respuesta a esta última cuestión nos basaremos en la obra de Ana Palacios, que realiza fotografía documental siempre vinculada a proyectos de cooperación al desarrollo en Asia y África subsahariana.

\section{Cómo citar este texto:}

Beatriz Guerrero González-Valerio (2018): La fotografía documental y la utopía, en Miguel Hernández Communication Journal, no9 (2), pp. 139 a 168. Universidad Miguel Hernández, UMH (Elche-Alicante). DOI: http://dx.doi.org/10.21134/mhcj.v0i9.251 


\title{
Documental Photography and the Utopia
}

\author{
Beatriz Guerrero González-Valerio | beguergo@ceu.es
}

\section{CEU Universidad San Pablo}

Keywords

"photography"; “documental"; "utopia"; "information";

"communication"; "social reformation"

Summary

1. Introduction.

2. Methodology

3. Results.

3.1. What we mean by Documentary Photography.

3.1.1. Purpose.

3.1.2. Common properties.

3.2. Documentary Photography today.

4. Discussion.

4.1. Documentary Photography and objectivity.

4.2. Documentary Photography and the passing of

time.

5. Conclusions.

6. Bibliography.

\begin{abstract}
Documental photography stands on its own in the sense that it uses the camera as an instrument that allows a certain situation to be known. Therefore, there is not just one single compromise with reality, but that it also believes in the conviction of an image. This documented intention in photography does not take place until the early stages of the XX Century. Its birthplace having taken place in the USA, guided by the hands of Jacob Riis and Lewis Hine, both advocating for a social
\end{abstract} photography perspective with the intention of ending and calling these issues into question. At the early stages of the XXI Century it was proven that the documented images still exist as well as serving a purpose. Two will be the main issues that well be addressing in this article, which well do our best to try to shed some light upon. First of all, that which could be understood when we mention the term documental photography, what traits a documented photography needs to bare and in second place, to make certain that current documental photography is still interested in bringing about reform or if it is still looking to influence its contemporary parts in order to make the world a better place. In our intention in trying to cast light on this issue, we will base that study upon Ana Palacios work's. She has always taken part in the field of documental photography linked to developmental projects in Asia and Sub-Saharan Africa.

\section{How to cite this text:}

Beatriz Guerrero González-Valerio (2018): Documental Photography and the Utopia, in Miguel Hernández Communication Journal, n9 (2), pp. 139 a 168. Universidad Miguel Hernández, UMH (Elche-Alicante). DOI: http://dx.doi.org/10.21134/mhcj.v0i9.251 


\section{Introducción}

Desde sus inicios, en el siglo XIX, la fotografía se ha debatido entre dos polos opuestos, documentar la realidad y representar los hechos, o expresar sentimientos e ilusiones, es decir, entre verdad o belleza. Sin embargo, no es en estos primeros años del siglo XIX cuando surge la fotografía documental, será más adelante cuando se decida hacer fotos con los códigos del documental y, sobre todo, para que se lean como documental. Esto no será hasta comienzos del siglo XX, como señala Margarita Ledo, "la acotación de la foto como documental, el desarrollo de la categoría documental para hacerla corresponder con fotos que reúnan determinadas propiedades es un fenómeno del siglo XX” (Ledo, 1998: 39).

Sin embargo, el término "documental” como tal, no se llegó a popularizar hasta la década de los años treinta, a raíz de una crítica de John Grierson en un periódico neoyorquino sobre la película Moana de Robert Flaherty, definiéndolo como un film con "valor documental". Con la palabra documentary reivindicaba una nueva categoría cinematográfica (Rodríguez Merchán, 2003: 45), aunque el término se estuvo usando con anterioridad, tanto en Europa como en EE.UU. Y del mundo del cine pasó a aplicarse también a la fotografía.

Los inicios de la fotografía documental se sitúan en Nueva York, a principios del siglo XX, con Jacob Riis, seguido de Lewis Hine y unos años más tarde, en la década de los treinta, con los fotógrafos de la Farm Security Administration, entre los que cabría citar a Dorothea Lange (18951965), a Margaret Bourke-White (1904-1971) y a Walker Evans (1903-1975) "su obra dio la pauta a este tipo de imagen con una visión rigurosa, no exenta de poesía” (Sougez, 1996: 404). No son los únicos, pero sí los más representativos. No se debe olvidar a Charles Marville que hizo reportajes sobre la vida de París, ni a John Thomson en las calles de Londres. "Thomson y un escritor Adolphe Smith fueron a explorar el Londres marginal y volvieron con una colección de vagabundos, mendigos y limpiabotas" (Jeffrey, 1981: 65).

Todos ellos tuvieron en común su preocupación social, el querer mostrar las desigualdades sociales y con sus fotografías denunciar situaciones indignas. Tras la Segunda Guerra Mundial, la fotografía documental como tal perdió algo de brío, sin embargo, sus principios fueron asumidos por el fotoperiodismo. Tanto Jacob Riis como Lewis Hine, utilizaron las imágenes porque fueron conscientes de su capacidad de subversión. Ambos realizaron fotografías de temática social, muy ligadas a connotaciones éticas, abogando por poner fin a ciertas injusticias. Estos fotógrafos actúan en un momento concreto, cuando el liberalismo de Estado y los movimientos progresistas de reforma constituían el clima ideológico en Estados Unidos.

También en EEUU, en los años 30, durante la Administración de Roosevelt, se promovieron toda una serie de prácticas documentales como el programa fotográfico de la Farm Security Administration. En todos estos casos el documental estuvo acompañado del mito de la objetividad periodística. Fue éste el periodo en el que se creyó en la fotografía como el mejor método de acceso a lo real. Esta categoría de fotografía documental a través de la cual se "pedía" a los miembros de las clases altas que rescataran a las clases oprimidas no pertenece solo al pasado, en el momento actual, como veremos más adelante, hay otros fotógrafos con la misma inquietud.

El debate anteriormente mencionado entre la fotografía documental y la artística, entre concretar lo real o idealizar lo real, hoy día está superado, ya que está plenamente asimilado que la actual fotografía documental puede tener aspectos estilísticos eclécticos. Ya en 1942, Roy Stryker, director del programa fotográfico de la Farm Security Administration señalaba que: "la actitud documental no implica menospreciar los elementos plásticos, que deben seguir siendo criterios esenciales en cualquier trabajo" (Newhall, 2002: 244). Asimismo, el profesor Lee 
Fontanella muestra una postura abierta, considerando que el documentalismo presenta muchas posibilidades. Aunque pueda tener unos denominadores comunes, no es una fórmula cerrada. El fotógrafo documentalista no deja de serlo por ser imaginativo en cuanto a su aproximación a la obra o en cuanto a la aplicación de técnicas fotográficas. Muestra de ello es esta cita del mencionado profesor, "nuestros fotógrafos documentalistas pueden realizar sus obras con ironía o sin ella, tener objetivos críticos o no; ser activos o pasivos en su propia postura ante sus temas" (Fontanella, 1992: 47).

Sin embargo, el título de este artículo presenta un término de significado poco claro, o por lo menos, no todo lo "concreto" que hubiéramos deseado. A la indefinición del término fotografía documental ha contribuido el hecho de que, dada la naturaleza de la fotografía, cualquier imagen tomada con una cámara fotográfica puede servir de documento en un momento dado. Otra muestra de la imprecisión del término imagen documental es la cantidad de calificativos diferentes que recibe, streetphoto, straightphoto, documentary photo, etc.

Además, nos encontramos con que hoy en día, cada vez se produce una mayor osmosis entre diferentes corrientes y estilos fotográficos, con lo cual no queda claro dónde están los límites entre lo puramente documental y la creatividad y, por otro lado, tampoco queda claro si podemos hablar de un proceder documental. A modo de ejemplo de que en las últimas décadas no resulta fácil establecer un límite entre lo exclusivamente creativo y lo puramente documental, observamos cómo algunas obras de fotógrafos de prensa están siendo objeto de grandes retrospectivas en museos y galerías. Documentos, por tanto, que pasan a adquirir una nueva categoría, la de obras de arte.

Dada la actual tesitura, consideramos pertinente llevar a cabo este estudio para plantear y tratar de clarificar qué entendemos por fotografía documental. Comenzaremos, por tanto, fijando qué entendemos por "fotografía documental", partiendo de que este término define un estilo fotográfico y tratando de mostrar cuáles son las propiedades comunes que debería tener una imagen para ser designada en la categoría de "documental". Por otro lado, nos plantearemos si esa intención de reforma, de poner fin a las injusticias que se observa en el nacimiento de la fotografía documental, sigue presente en el momento actual. Es decir, si podemos considerar que la utopía ${ }^{1}$ sigue existiendo.

\section{Metodología}

Hemos tomado como objeto de estudio la fotografía documental con el fin de establecer si existen una serie de rasgos o características comunes que debe poseer una fotografía para poder ser considerada documental o si, por el contrario, como cada vez sugieren más autores, no se pueden tratar de establecer clasificaciones dado que la línea es muy difusa. Para ello se ha procedido a una revisión y lectura de la bibliografía existente, de autores destacados en el tema como Eduardo Rodríguez Merchán, el profesor Susperregui o Margarita Ledo y otros autores consagrados como el profesor Lee Fontanella, Roland Barthes, Susan Sontag, Beaumont Newhall o Gisèle Freund.

Tras leer a los mencionados autores, se ha tratado de acotar el término fotografía documental y para ello se han establecido cuatro variables que van a actuar como factor de codificación, es decir, cuando una imagen cumpla y desarrolle unos determinados códigos nos hará entender que es una fotografía documental. Estos cuatro aspectos se han elegido por ser los elementos más repetidos y tenidos en cuenta por los autores anteriormente citados a la hora de referirse a la fotografía documental.

${ }^{1}$ El diccionario de la Real Academia Española, define utopía como: "isla imaginaria con un sistema político, social y legal perfecto, descrita por Tomás Moro en 1516”. Y añade a continuación otra definición, "plan, proyecto, doctrina o sistema deseables que parecen de muy difícil realización". 
Estas cuatro variables son, en primer lugar, el referente, ya que este es el punto de partida, la materia prima con la que se trabaja, pues en esta clase de imágenes el contenido y la temática son de gran importancia. En segundo lugar, la actitud del fotógrafo, su método de trabajo y el modo de aproximarse a la realidad. En tercer lugar, los objetivos perseguidos. Y, por último, el público, el modo de dirigirse al espectador y el soporte en que se hace, también será de suma importancia pues el lector actuará como factor de codificación.

Como punto de partida debemos discernir entre imagen documental ya que, en principio, "toda imagen fotográfica, por su condición de huella lumínica, es documental” (Alonso Martínez, 2002: 20) y otra cosa es el estilo documental. Es decir, durante el siglo XIX, "las primeras fotografías documentales eran noticias per se: su mérito estaba en existir, el documento (lo fotografiado) podía pasar a un segundo plano, pues lo importante, lo novedoso, lo noticiable era lo fotografiable, el hecho de que "eso" pudiera ser plasmado en una imagen" (Rodríguez Merchán, 2001: 382).

Sin embargo, con el paso de los años, va a haber un momento en que los fotógrafos pasarán del simple registro a describir el mundo con intención de comunicar claramente lo que sucede, respetando los hechos y sirviéndose en muchos casos de la influencia pública de las imágenes. De manera que la fotografía documental pasará a formar parte de la memoria colectiva, proponiendo perspectivas sobre cuestiones y acontecimientos.

El segundo objetivo consistirá en constatar si la fotografía documental actual sigue interesada en reformar, si sigue buscando persuadir a sus contemporáneos para cambiar y mejorar el mundo. Si todavía algunos autores utilizan la fotografía como medio de denuncia y demanda de cambios sociales, mostrando la realidad para apelar a la conciencia de sus contemporáneos, lo mismo que sucedió entre finales siglo XIX y principios del XX. Sin duda, los dos nombres vinculados a los incios de la fotografía como denuncia social son Jacob August Riis (18491914) y Lewis Wickes Hine (1874-1940). Si bien, como ya se ha indicado, no fueron los únicos.

Como señala la profesora Incorvaia, "hacia 1880 la idea del testimonio real, se constituyó en un elemento que, muchas veces, sirvió como toma de conciencia de un mundo industrializado que empezaba a padecer los cambios tecnológicos y políticos instalados en la sociedad" (Incorvaia, 2008, 114). En 1890, Jacob A. Riis, emigrante de origen danés, publicaba en Nueva York Cómo vive la otra mitad (2004, edición española), libro que obtuvo una gran repercusión y motivó una reforma urbanística en las zonas menos favorecidas de la ciudad. Ya en los primeros años del siglo XX, el sociólogo Lewis Hine comenzó realizando fotografías a los inmigrantes a su llegada a Ellis Island. Sin embargo, más célebres fueron sus trabajos sobre la explotación infantil en minas y fábricas textiles que incluso impulsaron la Ley de protección laboral de menores. En 1909, Hine llegó a publicar un texto reflexionando sobre el papel de la fotografía en el ámbito social: Social Photography. How the Camera May Help in the Social Uplift.

Para dar respuesta a esta última cuestión (un segundo objetivo): ¿podemos considerar que en el momento actual la fotografía documental sigue interesada en buscar la utopía?, nos basaremos en la obra y en una serie de entrevistas realizadas a la fotógrafa Ana Palacios, que realiza fotografía sobre las vulneraciones de los derechos humanos, principalmente en África subsahariana.

Ana Palacios nació en Zaragoza en 1972, estudió Ciencias de la Información en Pamplona y más tarde pudo cumplir su sueño, estudiando cine y fotografía en la Universidad de California (Los Ángeles). Estuvo más de quince años trabajando en la producción de cine, realizando, 
sobre todo, coproducciones internacionales con grandes directores. Sin embargo, en un momento dado comenzó a diluirse la ilusión por su trabajo. Como consecuencia de esa catarsis, en 2010, se va tres meses a la India fotografiando proyectos de cooperación. Al volver a España logra publicar las fotos y allí se da cuenta de la fuerza de la fotografía para cambiar las cosas, para cambiar el mundo. Desde entonces, su vida cambia radicalmente, difuminándose su adicción al cine y estallando la de documentar proyectos humanitarios. Como a ella misma le gusta recalcar: "cambié el glamur de Hollywood por las escuelas africanas" (Palacios, 2018).

A partir de este momento empieza su giro hacia la fotografía documental, poniendo su atención en la infancia y la vulneración de los derechos humanos en África occidental. Siempre vinculada a proyectos de cooperación al desarrollo a través de ONG's como UNICEF, Manos Unidas o Mensajeros de la Paz. Su obra ha sido galardonada con premios internacionales, expuesta y publicada en los cinco continentes. Por citar algunos de los medios en los que ha publicado: Stern, The Guardian, Daily Mirror, 6 Mois, El País, Yo Dona, XL Semanal, Papel y Tiempo. Así mismo, ha publicado ya dos libros y el tercero está a punto de ver la luz.

\section{Resultados}

\subsection{Qué entendemos por Fotografía Documental}

Generalmente cuando hablamos de documento nos referimos a algo que es portador de información, que es susceptible de ser empleado para probar alguna cosa entendiendo que los datos son fidedignos. Por sus características intrínsecas una fotografía obtiene una realidad observable y verificable, tiene un valor de prueba, de prueba visible. Esta capacidad testimonial está basada en su alto grado de reproducción icónica. La cualidad de autenticidad de la fotografía conlleva que las imágenes constaten, porten información, testimonien una realidad demostrable. La fotografía, como posibilidad de inscripción directa de la realidad, por su propia mecánica de realización se anuncia como valor de prueba, de que algo se convierte en imagen sin necesidad de modificar todo aquello que entra a formar parte del campo de visión, sin tener que sufrir alteraciones sustanciales (Ledo, 1998: 36)

El fotógrafo documental se va a servir de este poder testimonial de la fotografía. Se beneficia de su carácter de huella, de que el componente mecánico de la fotografía convierte los hechos en más creíbles y que socialmente la fotografía se acepta por su aura de certeza. Joan Costa en su obra El lenguaje fotográfico (1977: 47) ya diría que en este tipo de imágenes la actitud predominante del fotógrafo es la reproductiva, obteniendo, por tanto, una foto documento porque en ella predomina el objeto real. El fotógrafo se orienta hacia el objeto obteniendo una imagen que por su analogía será sinónimo de veracidad e identidad (idéntico al objeto. Esto unido a la idea de "testimonio" (el fotógrafo ha sido testigo presencial) equivale a la función de documento. El fotógrafo intentará no interferir, no modificar la realidad y evitar cualquier ambigüedad. Y con esta apropiación poder comunicar valores como verdad y credibilidad.

\subsubsection{Propósito}

Un aspecto de suma importancia dentro de la fotografía documental es el propósito con el que se hace. La fotografía documental nace con un propósito mayormente pragmático, es decir, subyace una función utilitaria. El profesor Susperregui, lo mismo que en su momento el fotógrafo Walker Evans, distinguen entre el "estilo" documental y la "fotografía", para ellos cualquier fotografía puede servir como documento en una determinada circunstancia, pero 
cuando a una fotografía se le dota desde su origen de un estilo documental significa que esa imagen ha nacido con una intención perfectamente definida (Susperregui, 2000: 261). Tomando este matiz como punto de partida tendríamos entonces una de las claves sobre la fotografía documental, nacer con una intención. En el campo de la fotografía, la intención documental no se manifestará hasta los inicios del siglo XX. Podríamos decir que el objetivo prioritario es el de hacer constar algo, o ilustrar un hecho, hacer llegar al lector o receptor un testimonio, a veces incluso una preocupación.

\subsubsection{Propiedades comunes}

Se han establecido una serie de constantes que harán identificar una fotografía como documental, atendiendo a las cuatro variables ya mencionadas, el referente, la actitud del fotógrafo, los objetivos y el público.

Respecto al referente, en la fotografía documental los hechos son la materia prima. El punto de partida lo constituye un sujeto o una situación real, es decir, se parte siempre de un referente real. Cuando hablamos de fotografía documental reconocemos un alto grado de iconicidad con el referente real. Además, generalmente, el referente no se modifica, si bien esto no significa que no se pueda reubicar en el espacio u organizar. Son imágenes, por tanto, en las que se pretende destacar el efecto real. Por ello, solo se interviene en lo estrictamente necesario como la selección, el encuadre, etc. De ahí que el referente suela ser fácilmente reconocible, por lo menos en el momento en que se realiza. Las imágenes por sí solas son capaces de transmitir información.

No obstante, el hecho de que el contenido sea de gran importancia no significa que se descuide la forma o que no pueda haber una experimentación formal. El autor es libre para elegir su estilo. Puede haber fotografía documental en la que el contenido y la estética visual estén al mismo nivel. El hecho de buscar una estética elaborada o una elegancia formal no tiene por qué restar eficacia al mensaje. Tradicionalmente se ha identificado la fotografía documental con el uso del blanco y negro. Aunque hoy en día el color está perfectamente admitido con la ventaja de que el grado de iconicidad es mayor. Estas opciones expresivas ya no se discuten.

Con respecto a la temática, aún siendo muy variada, podemos afirmar que suele predominar una mirada atenta a la naturaleza humana, a situaciones reales preferentemente de tipo social o de interés humano. Suele haber una inclinación hacia los fenómenos sociales y el desarrollo, pero esto no es determinante.

Por lo que respecta a la actitud del fotógrafo, un acontecimiento va a ser seguido y registrado por un testigo, el fotógrafo. De manera que este se convierte en testigo presencial de aquello que está fotografiando. El fotógrafo capta y registra el acontecimiento a medida que acontece. Dado que se pretenden realizar imágenes con profundidad, lo aconsejable es proceder previa reflexión y disponer de tiempo.

Con respecto a su postura podemos apreciar que el fotógrafo se interesa por la realidad circundante, por lo que ocurre fuera de sí mismo, la gente y la sociedad en derredor, es un observador de su momento. Dado su compromiso con la realidad el fotógrafo debe ir donde ocurre la acción. Por tanto, ni el escenario, ni el tiempo son de libre elección, el fotógrafo debe adaptarse al lugar donde ocurren los hechos y a sus múltiples circunstancias.

Su modo de aproximarse consiste en acercarse al acontecimiento desde fuera, en estar en contacto directo con los hechos y en seguirlos. Uno de sus méritos es la cercanía y proximidad a lo real pero sin intervenir, tratando de no influir en lo que pasa delante de la cámara. Es decir, 
hay un respeto por los acontecimientos. La pretendida invisibilidad del autor tras la fotografía ayuda a que esta resulte más verídica y sincera.

Además de la inmediatez y la contemporaneidad debemos destacar la singularidad, el aspecto no repetible de muchas fotografías documentales. Así lo entendía Henri Cartier-Bresson: "De todos los medios de expresión, la fotografía es el único que fija el instante preciso. Jugamos con cosas que desaparecen y que, una vez desaparecidas, es imposible revivir. No se puede retocar el tema; como mucho se puede hacer una selección de imágenes" (Cartier-Bresson, 2003: 17).

La no intervención del fotógrafo, el hecho de que las imágenes no sean construidas hace que los personajes sean presentados, es decir, no actúan, ni son actores. No obstante, debemos ser conscientes de que la presencia del fotógrafo y su cámara, por muy objetiva que esa presencia quiera ser, pueden afectar al sujeto fotografiado y hacer que éste pose, afectando al normal desarrollo de los hechos reales. Así lo expresa el semiólogo Roland Barthes: "Entonces, cuando me siento observado por el objetivo, todo cambia: me constituyo en el acto de 'posar', me fabrico instantáneamente otro cuerpo, me transformo por adelantado en imagen" (Barthes, 1982: 41).

Aunque no intervenga, el fotógrafo se implica con lo que está fotografiando, se compenetra con lo que ha captado. La fotografía documental aúna el respeto por los hechos con la interpretación subjetiva por parte del fotógrafo. Las fotografías registradas revelarán los valores, el estilo, el temperamento, el enfoque y las preocupaciones de quien las ha tomado. El fotógrafo hace una interpretación personal, un comentario de la realidad. Aunque en la elaboración de toda imagen haya elementos subjetivos, aunque la objetividad absoluta no sea posible, sí es deseable, al menos en lo que a fotografía documental se refiere, cierta imparcialidad en la representación de la realidad.

El tercer aspecto se refiere a los objetivos, el fotógrafo busca verificar, plasmar la huella de lo real. Así lo expresaba el fotógrafo Sebastiäo Salgado. "Nuestro trabajo nos lleva a lugares donde no acceden los demás, y nuestra tarea consiste en mostrarles lo que de otra manera les hubiera sido imposible ver. Los fotógrafos no crean los conflictos, como a veces se sugiere, son simplemente un 'espejo crítico’” (Salgado, 1985: s. pág.). Efectivamente, el trabajo de estos fotógrafos consiste en sacar a la luz historias, pero alguno de ellos no se detiene ahí, no se conforma sólo con mostrar y puede ir más lejos, buscando provocar o estimular respuestas, conformar actitudes y movilizar conciencias.

Este es quizás unos de los aspectos de mayor importancia, el compromiso por parte del fotógrafo que realiza las imágenes. Así lo expresaba el fotógrafo Joan Colom, ganador del Premio Nacional de Fotografía en 2002. "Soy fotógrafo y como fotógrafo no me puedo zafar de esa realidad. Es mi compromiso estar allí. El instinto del fotógrafo siempre tiene que ir tras la humanidad" (Colom en Martínez, 2003).

Y, por último, el público. Para la fotografía documental tiene gran importancia el público, su difusión pública, ya que estas imágenes se hacen para que las vea un tercero. Por tanto, la exigencia de difusión está muy ligada a la fotografía documental. Además de la imagen documental que realiza el fotógrafo es necesario un espectador que reconozca esa imagen como documento, que sea capaz de hacer una lectura documental. No se puede obviar el papel desarrollado por el lector, lo decisivo de su actitud en la introducción de sentido "documental" en la imagen. El espectador va a hacer una lectura documental ya que gracias al alto grado de iconicidad podrá reconocer con mayor o menor claridad la realidad a que se refiere la imagen. Un público que 
cree, no que lo que ve sea la realidad, sino que lo que ve ha existido en lo real.

El modo de dirigirse al espectador tendrá también gran trascendencia, para que sea capaz de percibir que las imágenes han sido construidas según los cánones del documental. Aspectos como la selección del material que se va a exponer o publicar, la adjunción del texto verbal que acompañará a la fotografía, etc. tendrán importantes repercusiones en la significación definitiva del mensaje gráfico. Como también es indudable que la lectura de una fotografía estará condicionada por aspectos espaciales, como el lugar y la situación de la recepción. El público asumirá la "veracidad" de las imágenes por el grado de respeto que éstas mantengan con la realidad que el receptor conoce. Vemos cómo el contexto (porque nos da información) y el receptor (por su conocimiento previo) resultan imprescindibles para la significación de las imágenes.

El sentido de una fotografía dependerá del dominio que tengan los lectores sobre el tema en cuestión y del contexto, pues la misma imagen puede ser presentada en múltiples contextos diferentes. Todas estas coyunturas hacen que una imagen pueda adquirir un significado particular dependiendo de las circunstancias concretas en que vayan a ser leída por los destinatarios. El significado, por tanto, no es estable. "La obra fotográfica no es ya entregada llave en mano, con sus instrucciones de uso y sus prohibiciones: es una obra abierta, necesariamente abierta, obra viva que adquiere una dimensión nueva y un destino nuevo en cada realización” (Sontang, 1996: 116).

A la hora de analizar una fotografía documental debe hacerse dentro de su contexto original. Beaumont Newhall consideraba que para que una foto pueda ser aceptada como documento, debe estar documentada, es decir situada en el espacio y en el tiempo. Por ello, será fundamental contextualizar a los autores y sus imágenes en sus respectivos momentos históricos.

\subsection{La fotografía documental en la actualidad}

En la actualidad, el destino de la fotografía documental suele ser esencialmente libros, galerías, prensa semanal o medios digitales. Desde finales del siglo XX el fotógrafo documentalista concibe su trabajo sin enfocarse tanto en los media para poder así ofrecer una visión más libre, más independiente e incluso más experimental.

Algunos fotógrafos documentalistas se sienten más atraídos por los canales artísticos dada la mayor remuneración y prestigio, siendo su principal fuente de ingresos la venta de su obra a través de las galerías. Sin embargo, otros fotógrafos documentalistas sí gustan de la prensa por la resonancia que puedan alcanzar sus testimonios, por la posibilidad de compartir masivamente aspectos concretos de la realidad. Actualmente, una u otra opción, no son excluyentes. Nos encontramos además con que desde finales de siglo pasado un buen número de fotógrafos adopta el discurso del reportaje, readaptando los postulados periodísticos a sus propias inquietudes personales como creadores.

\section{Discusión}

\subsection{La fotografía documental y la objetividad}

Lo documental ha ido siempre acompañado de la polémica sobre la objetividad. Durante el siglo XIX la fotografía era considerada totalmente objetiva y verídica, de ahí que se convirtiera 
en "testimonio fiel" de todos los hechos importantes pues en ningún momento era puesta en duda. En la actualidad, aún partiendo de que el fotógrafo se propone comunicar claramente lo que sucede, se acepta que la imagen no resulta totalmente objetiva. En 1948, Eugene Smith ya afirmó: "es imposible ser totalmente objetivo. Honesto sí, objetivo no" (Fontcuberta, 2003: 209). Será precisamente alrededor de los años cincuenta del siglo XX cuando los fotógrafos documentalistas rompan con la pretendida objetividad.

No debe olvidarse que, además de una interpretación del punto de vista del operador, también hay un condicionante técnico - la lente elegida, el ISO, la utilización del color o el blanco y negro, la iluminación, la edición y reproducción posterior, etc.- - Todos estos elementos técnicos pueden actuar como elementos persuasivos. La cámara no es un simple instrumento, sus limitaciones técnicas y las distorsiones que ocasiona se registran en forma de significado. "Una fotografía no es lo que hay. Es lo que el fotógrafo nos da a ver. La mirada de quien ha disparado el obturador ha construido una imagen a través de la selección, el encuadre, la luz... La mirada crea la escena y no al revés" (Parreño, 2005: 22).

\subsection{La fotografía documental y el paso del tiempo}

Una imagen documental tiene dos momentos, por un lado, el instante en que la imagen es captada sería el "inmediato". Este momento sería el válido como testimonio, como evidencia. Y un segundo momento, normalmente muy posterior, en el que pierde poder de argumentación, pierde la compresión social y a menudo su carga emocional, pero aumenta el placer estético.

Por tanto, es fácil que el sentido de alguna fotografía documental cambie en el transcurso del tiempo debido al distanciamiento histórico entre el espectador y el referente. La falta de inmediatez histórica hará que disminuya la cualidad de documento. Para el profesor Fontanella esto no significa que las fotografías se invaliden, simplemente se alteran los propósitos documentales y adquieren valores distintos. Esta particularidad lleva a que la intencionalidad no sea estable, a que no se puede determinar en todas las ocasiones. El sentido de una fotografía podrá verse alterado con el paso del tiempo.

\subsection{Ana Palacios y la utopía}

Como ya se indicó anteriormente, los tres grandes proyectos de la fotógrafa se han publicado en tres libros. El primero de ellos en 2015, Art in Movement editado por La Fábrica. Con él da a conocer una iniciativa promovida por una ONG en Uganda, que consiste en utilizar la enseñanza de ciertas disciplinas artísticas con el fin de que sirvan como herramienta para el cambio social entre los jóvenes. Es decir, se pretende cortar el círculo vicioso de la pobreza a través del arte. Ya que, gracias a aprender, practicar y desarrollar alguna disciplina artística, niños y jóvenes que están en riesgo de exlusión social comienzan a creer en ellos mismos. En el libro se cuentan nueve historias y la forma de significarlo elegida por la fotógrafa es con un salto.

En 2016 publicó Albino (ver imagen 1), patrocinado por la Diputación y el Ayuntamiento de Huesca. A través de este trabajo pone de manifiesto la situación de los albinos en Tanzania. Destacar que los beneficios del libro, Ana Palacios los destina a la ONG que atiende a estos chicos, mediante la prevención y la formación de personal sanitario. Acompaña al libro una exposición patrocinada por Telefónica, en itinerancia por distintas salas españolas. Palacios recalca que, además de ser estigmatizados y marginados, el mayor problema que tienen las personas albinas es el cáncer de piel. Su esperanza de vida se sitúa en los 30 años. Para realizar 
este proyecto, Ana estuvo en Tanzania, ya que es el país con el mayor número de albinos del mundo.

Su último libro, que se editará en breve, es Niños esclavos. La puerta de atrás ${ }^{2}$, proyecto en el que se centra en la reinserción de los niños víctimas de trata en África Occidental. Este último trabajo, además del libro, publicado en inglés y en castellano, consta también de una exposición y un documental. El trabajo sobre los niños esclavos abarca todo el proceso, desde la esclavitud, cómo se rehabilitan, e incluso cómo se insertan ya que algunos son devueltos a sus familias. Siempre con un enfoque característico de Ana Palacios, desde la esperanza. Para este trabajo ha estado en Togo, en Benín y en Gabón.

Si aplicamos a la obra de Ana Palacios las cuatro variables establecidas previamente, constatamos que su trabajo cumple con las propiedades comunes para que su obra pueda ser entendida como fotografía documental. En primer lugar, su trabajo surge siempre de una intención definida, hay un pragmatismo, un utilitarismo en su obra, que en su caso es luchar por causas injustas o de desigualdad, y tratar de catalizar el cambio, usando la cámara como instrumento (Palacios, 2018).

En relación al referente, observamos cómo Ana Palacios parte de un referente, de una situación real, su mirada se centra en la naturaleza humana, en situaciones reales de tipo social. En las imágenes de Ana, lo mismo que en cualquier fotografía documental, el contenido y la temática son de gran importancia. Ana considera que los temas que fotografía son importantes, es consciente de que posiblemente no son primera página, pero considera que hay que contarlos: "Son los destinos los que me eligen a mí. Yo me enamoro de las historias y ellas me llevan a unos destinos"

(Palacios en Lambán, 2014). A este respecto a Ana le gusta hacer hincapié en su libertad como fotógrafa, en el sentido de que ella elige a las ONG's, "voy dónde quiero, con quien quiero y cuando quiero" (Palacios, 2018).

Respecto a su actitud como fotógrafa, hay un respeto por los acontecimientos. Considera de gran importancia el rigor y la profundidad en la documentación. Intenta, además, que su obra tenga una manera artística pero no es lo prioritario. Para Ana la estética es importante porque busca llegar a un público que se pueda acercar a su obra por el tema estético.

En relación a sus objetivos, ella misma indica que su "unico objetivo es mostrar realidades invisibles y sensibilizar a quien quiera mirar a este lado porque creo que otro mundo es posible" (Palacios, 2018). Podemos decir, por tanto, que su obra tiene una función social, ya que busca que se conozcan ciertas realidades, dar visibilidad a comunidades vulnerables; pero, sobre todo, trata de mostrar la esperanza, aunque sean temas dolorosos.

Podemos establecer dos finalidades: en primer lugar, sensibilizar y dar visibilidad a temas importantes. Mostrar las vulneraciones de los Derechos Humanos. Siendo plenamente de que no son breaking news sino lo que está en sombra. Y, en segundo lugar, poner en valor el trabajo de las ONG'S. Ana cada vez que habla de su obra menciona siempre a las ONG'S con las que ha trabajado para darles visibilidad —adquiere con ellas ese compromiso- También les da alguna de sus fotos para que las usen en su página web o en sus revistas, etc. A Ana le mueve lo gratificante que le resulta el trabajo y que este pueda servir de ayuda. Su motor profesional es la pasión y la gran satisfacción personal.

${ }^{2}$ Durante la edición de este artículo el libro ha sido publicado Ana Palacios: niños esclavos: la puerta de atrás = Slave children: the back door. Madrid: La Fábrica, 2018. 


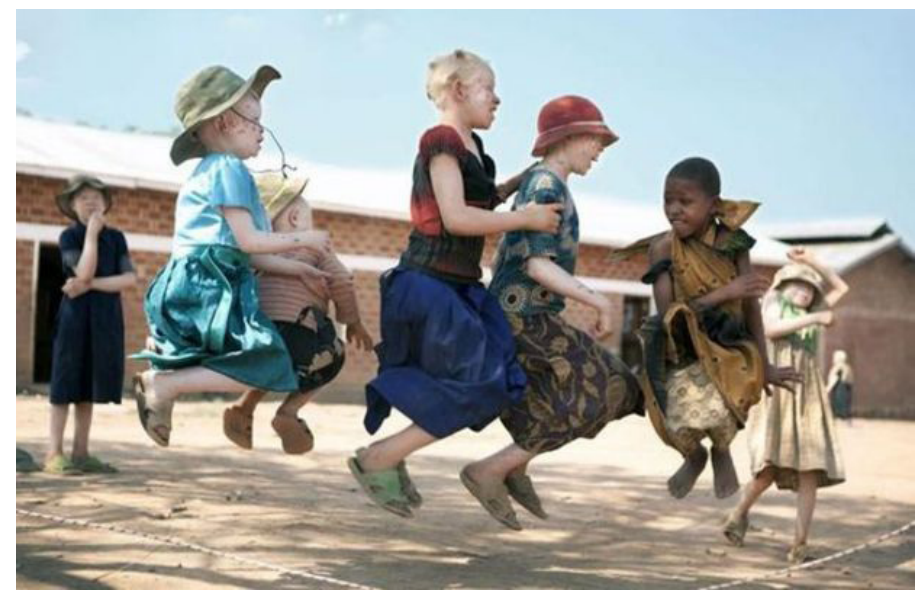

Imagen 1. Albino. Ana Palacios, 2015. Fuente: https://www.ana-palacios.com/albino-tanzania - 29

Y, por último, el público. Ana mueve su trabajo en todo tipo de prensa, organiza exposiciones, realiza vídeos, publica ibros, todo ello para ser sostenible. Ya que es plenamente consciente de la importancia de la difusión en medios, además de todo tipo de medios (prensa y revistas de todo el mundo, redes sociales, etc.) y de saber mover el material. Una de sus estrategias es tratar de llegar al público por otras rutas que no sean los habituales canales de difusión. Así mismo, considera que es muy importante saber rodearse de los mejores (un buen editor para sus libros, o un buen realizador para sus vídeos), por ejemplo, fotógrafos de la talla de Chema Conesa, Gervasio Sánchez o Isabel Muñoz han colaborado en sus publicaciones, y la producción de obra y nivelados los lleva Castro Prieto.

Una ventaja con la que cuenta es que ha podido trasladar su conocimiento del mundo del cine a gran escala, sobre todo el aspecto de la difusión de la obra y de cómo encontrar financiación, por ejemplo, busca patrocinios de empresas con fines sociales. Considera que lo social bien contado y bien vestido sí interesa, ya que todos tenemos esa sensibilidad. Incide en que la cuestión es cómo se presentan. Ana insiste en que hay que presentarlo de manera interesante. Ella intenta ofrecerlo a plataformas no tendentes a lo social, considera que cuanto más generalistas sean los medios, mucho mejor.

¿Podemos establecer una búsqueda de la utopía en la obra de Ana Palacios? A juzgar por estas dos frases se diría que sí: "poco a poco vas sembrando, yo ya llevo ocho años sembrando" (Palacios, 2018), "la fotografía es una herramienta poderosísima para el cambio social" (Palacios en Ester, 2016).

\section{Conclusiones}

1) Se puede establecer que el término "fotografía documental" se refiere a aquellas imágenes realizadas con intención de efectuar un registro de la realidad, respetando los hechos y sin quebrantar la veracidad del relato, en lugar de inspirar o de expresar los sentimientos más íntimos del fotógrafo. Por tanto, entre las principales conclusiones debemos destacar que una de las claves para entender una fotografía como documental va a estar en la intención del fotógrafo.

2) Parece que cuanto más claros estén los referentes en el mundo real (imágenes sin idealizar, sin 
personalizar) y la intención del fotógrafo, mayor será la cualidad documental de una fotografía; debido a que en este tipo de imágenes la realidad aparecerá subrayada, no reemplazada.

3) La categoría "documental" designa imágenes que principalmente confían en la cámara pues se basan en el efecto-verdad que se establece con el referente, decretando, por tanto, que la imagen lleva implícito el valor de testimonio. La fotografía documental es una imagen que constata, que certifica un acontecimiento, que se basa en la capacidad de la fotografía para acercar la realidad al lector de imágenes, lo cual no significa que la foto documental sea la verdad, ni la única posibilidad fotográfica.

4) El sentido de la palabra documental ha ido cambiando con el tiempo, desde finales de siglo XX nos encontramos con una gran diversidad de propuestas. En los últimos años se ha producido una transformación conceptual de la fotografía documental. Entre otras cosas porque determinados autores la han reinventado y la han readaptado a sus inquietudes como creadores.

5) Así mismo, en la actualidad, la fotografía documental se ha ido acercando tanto a los circuitos artísticos que a veces resulta difícil acotar los territorios. Este acercamiento implica una mayor libertad expresiva, una ruptura de la visión neutra, una búsqueda de la experimentación y un mayor protagonismo de los fotógrafos como creadores. Todo ello sin perder su implicación con la realidad.

6) Dentro de sus múltiples variedades, la fotografía documental actual se caracteriza por su afán descriptivo de la época en que vive el autor con todo lujo de detalles (valores, comportamientos, afectos, retratos, paisajes, objetos cotidianos), por un mayor escepticismo (ya no hay una confianza ciega en la posibilidad de cambios generales), por no buscar un pacto con el receptor (ya no aspira a contar con su apoyo, con su complicidad) y por el retorno de la subjetividad (su obra se impregna de su personal punto de vista, los fotógrafos actuales no muestran reparos en mostrar su peculiar forma de entender el mundo).

7) Podemos afirmar que el documental realizado con la intención de mejorar el mundo sigue existiendo y funcionando. Así como algunos fotógrafos han dirigido el documental hacia unos fines más personales, sigue existiendo una serie de fotógrafos documentalistas interesados en reformar y en persuadir a sus coetáneos de la necesidad de enderezar el mundo. Fotógrafos para los cuales el documental sigue unido a la palabra compromiso y a la idea de reformismo. En una palabra, que no han renunciado a la utopía. Entre ellos se encuentra Ana Palacios, cuya intención es que la fotografía sea un motor de cambio.

\section{Bibliografía}

Alonso Martínez, F. (2002). Daguerrotipistas, calotipistas y su imagen de la España del siglo XIX. Gerona: CCG Ediciones.

Barthes, R. (1982). La cámara lúcida. Barcelona: Gustavo Gili.

Cartier-Bresson, H. (2003). Fotografiar del natural. Barcelona: Gustavo Gili.

Costa, J. (1977). El lenguaje fotográfico. Madrid: Ibérico Europea de Ediciones. 
Ester, B. (2016). "La fotografía es una herramienta poderosísima para el cambio social”. En 21 la revista cristina de hoy. Disponible en: https://goo.gl/mPDJDH

Fontanella, L. [et al.] (1992). "Los límites de la fotografía documental". En Open Spain/ España abierta: Fotografía Documental Contemporánea en España = Open Spain: contemporary documentary photography in Spain. Barcelona: Lunwerg.

Fontcuberta, J. (ed.) (2003). Estética fotográfica. Barcelona: Gustavo Gili.

Incorvaia, M. S. (diciembre 2008). Fotografía y Realidad. Cuadernos del Centro de Estudios de Diseño y Comunicación, $n^{0}$ 27, pp 111-119. Disponible en: https://goo.gl/XyKbi7

Jeffrey, I (1981). La fotografía. Londres: Thames and Hudson.

Lambán, A. (2014). “Entrevista. Ana Palacios” En Fotógrafos en Zaragoza. Disponible en: https:/ / goo.gl/eaSu4L

Ledo, M. (1998). Documentalismo fotográfico. Éxodos e identidad. Madrid: Ediciones Cátedra. Signo e Imagen.

Martínez, J. (15 de 1 de 2003) "Acercándonos a Joan Colom, Premio Nacional de Fotografía de España 2002”. En Eixdiari. Disponible en: https://goo.gl/ECZ2dC

Newhall, B. (2002). Historia de la Fotografía. Barcelona: Gustavo Gili.

Palacios, A (2016). Albino. Barcelona: Tenov.

- (2018). Comunicación personal, 13-03-2018. Madrid: Universidad CEU San Pablo.

Parreño, J. M. (2005). Miradas de mujer. 20 fotógrafas españolas. Segovia: Museo de Arte Contemporáneo Esteban Vicente.

Riis, J. (2004). Cómo vive la otra mitad: estudios entre las casas de vecindad de Nueva York. Madrid: Alba.

Rodríguez Merchán, E. (2001). La realidad fragmentada: una propuesta de estudio sobre la fotografía y la evolución de su uso informativo. Madrid: Editorial de la Universidad Complutense. Tesis doctoral. Segunda publicación en formato CD-ROM, Editorial de la Universidad Complutense. ISBN: 84-669-0082-9

- (2003). Una historia de la fotografía en prensa. En Caballo, D. (Ed.) Fotoperiodismo y edición. Historia y límites jurídicos (pp. 16-96). Madrid: Universitas.

Salgado, S. [et al.] (1995). World Press Photo. Este crítico espejo. 1955 - 1995. Madrid: Omnicón.

Sontag, S. (1996) Sobre la fotografía. Barcelona: Edhasa.

Sougez, M. L. (1996). Historia de la Fotografía. Madrid: Manuales de Arte Cátedra.

Susperregui, J. M. (2000). Fundamentos de la fotografía. Bilbao: Servicio Editorial Universidad del País Vasco. 
MHCJ no 9 (2) | Año 2018 - Artículo no 10 (125) - Páginas 293 a 307 - mhjournal.org

\section{(c). (i) (2)}

Licencia Creative Commons

Miguel Hernández Communication Journal

mhjournal.org

\section{Cómo citar este texto:}

Beatriz Guerrero González-Valerio (2018): La fotografía documental y la utopía, en Miguel Hernández Communication Journal, $\mathrm{n}^{\circ} 9$ (2), pp. 293 a 307. Universidad Miguel Hernández, UMH (Elche-Alicante). DOI: http://dx.doi.org/10.21134/mhcj.v0i9.251 